\title{
Adjustment of Demand Deposit Series
}

The demand deposit component of the money stock has been adjusted to correct for an understatement of these deposits, which arose from an increasing volume of cash items generated by an increasing volume of Eurodollar transactions. The adjusted series indicates that the growth of demand deposits since mid-1967 has been greater than previously reported.

The demand deposit component of money is calculated by subtracting several items, including cash items in process of collection, from gross demand deposits. These deductions are made to avoid double counting. The rapidly growing volume of drafts used in transferring or repaying Eurodollar borrowings, usually referred to as "bills payable checks" and "London checks", were not included in gross deposits by the issuing bank. However, these checks were included in the cash items of the receiving bank, and as such were deducted from gross demand deposits. The cash items generated in this manner and deducted from gross demand deposits caused an unwarranted reduction in net demand deposits. As a result there had been a growing understatement of the demand deposit component of money.

Regulation D of the Federal Reserve System was revised, effective July 31, 1969, so that bills payable checks and London checks used in the borrowing and repayment of Eurodollars must now be included in gross deposits of the issuing banks, as well as in cash items in process of collection. As a result, since early August the understatement of demand deposits caused by excluding bills payable checks and London checks from gross demand deposits has been eliminated. Revision of the demand deposit data from June 1967 through July 1969 was based on a survey of those banks thought to be most involved in Eurodollar transactions.

Before the adjustment, the data indicated that demand deposits had risen at a 1.1 per cent annual rate from last December to July. The adjusted series indicates that demand deposits rose at a 3.3 per cent rate in this period. The revised rate is still substantially less than the 6.2 per cent rise in 1968 in the former series and the 6.9 per cent in crease in the new series. Also, both series show a much slower growth in money during the summer than earlier this year.

In the near future demand deposit data will be revised again in accordance with the results of an annual review of seasonal adiustment factors and the incorporation of net benchmark adjustments for nonmember bank deposits. 